\section{Trinexapac-ethyl Does Not Increase Total Nonstructural Carbohydrate Content in Leaves, Crowns, and Roots of Tall Fescue}

\author{
W.E. Richie, R.L. Green ${ }^{1}$, and F. Merino \\ Department of Botany and Plant Sciences, University of California-Riverside, \\ Riverside, CA 92521-0124
}

Additional index words. Festuca arundinacea, growth regulator, growth retardant, prestress conditioning, turfgrass

\begin{abstract}
Turfgrass growth regulators (TGRs) are an effective means of reducing vertical shoot growth and the production of clippings of tall fescue (Festuca arundinacea Schreb.). Recently, using TGRs has been suggested as a way to acclimate or precondition turfgrass to stress conditions, possibly through total nonstructural carbohydrate (TNC) accumulations and altered TNC partitioning. The TNC may accumulate in response to growth suppression associated with the TGR application. The objective of this study on tall fescue was to determine the effect of a single trinexapac-ethyl (TE) application on tissue weight and on TNC concentration and weight in leaves, crowns, and roots when sampled 6 to 7 weeks following TE application. This sampling time was chosen to coincide with the 28- to 56-day callback schedule that professional lawn care personnel follow when working with tall fescue. In 1995, a high level of turfgrass maintenance was used, consisting of $\mathbf{N}$ applications at $49 \mathrm{~kg} \cdot \mathrm{ha}^{-1}$ per month and two mowings per week, while in 1996 a moderate level was used, consisting of $\mathrm{N}$ applications at $24 \mathrm{~kg} \cdot \mathrm{ha}^{-1}$ per month and one mowing per week. Though TE provided reasonable inhibition of clipping growth for a 4-week period during both years, we observed no increase in tissue weight or in TNC concentration or weight in leaves, crowns, and roots when sampled 6 to 7 weeks after treatment. Chemical name used: [4(cyclopropyl- $\alpha$-hydroxy-methylene)-3,5-dioxocyclohexanecarboxylic acid ethyl ester] (trinexapac-ethyl).
\end{abstract}

Turfgrass growth regulators can provide a number of important roles in the turfgrass industry. They serve to suppress turfgrass growth, which reduces the labor requirement for mowing and other cultural practices. Furthermore, TGRs can suppress seedhead development, resulting in improved turfgrass quality. Recently, interest has increased in using TGRs to acclimate or precondition turfgrasses to stress conditions through chemical effects on soluble carbohydrate accumulation and partitioning. These chemicals influence TNC levels to some degree (Cooper et al., 1988; Han et al., 1998; Hanson and Branham, 1987; Qian and Engelke, 1999; Spak et al., 1993; Watschke, 1976), but these effects are not well understood. Generally, TNC is defined as reserve carbohydrate that can be mobilized and used as an energy source by the plant. It consists primarily of reducing sugars (glucose and fructose), nonreducing sugar (sucrose), fructosans, and starches (White, 1973).

Nelson et al. (1986) hypothesized that reducing leaf elongation rates would increase

Received for publication 27 Mar. 2000. Accepted for publication 21 Sept. 2000. The cost of publishing this paper was defrayed in part by the payment of page charges. Under postal regulations, this paper therefore must be hereby marked advertisement solely to indicate this fact.

${ }^{1}$ To whom reprint requests should be addressed. E-mail address: robert.green@ucr.edu soluble carbohydrate levels in axillary buds. Tillering of tall fescue is correlated with slower leaf elongation rates (Jones et al., 1979). Rate of accumulation of TNC is inversely related to growth rates of grasses (McCarty, 1935). Accordingly, Spak et al. (1993) suggested that chemically suppressing foliar and seedhead development might increase TNC partitioning and availability. Watschke (1976) hypothesized that TNC would accumulate in response to chemical growth suppression and could then provide energy for growth during stress periods. Moderate to severe drought stress in turfgrasses normally results in some degree of leaf firing and senescence. Subsequent plant growth and recovery requires that new leaves grow from meristematic regions in the crown or along the plant stem. This growth is primarily dependent upon reserve carbohydrates, since photosynthetic area is reduced or unavailable because of leaf senescence (Booysen and Nelson, 1975; White, 1973). The major carbohydrate storage region in perennial grasses is the lower part of the stem (crown, including leaf and stem bases; stolons; corms; and rhizomes), and accumulation of reserve carbohydrates in these areas prior to the onset of drought stress could be beneficial.

White et al. (1992) indicated that the primary mechanism of turgor maintenance in tall fescue during drought stress is low basal osmotic potential and osmotic adjustment. Similar conclusions were drawn by Perdomo et al.
(1996) with regard to turgor maintenance in Kentucky bluegrass (Poapratensis L.). Soluble sugars, a component of TNC, are one of the major solutes contributing to osmotic adjustment in the leaves of many plant species (Morgan, 1984).

The accumulation of TNC in turfgrass can play a role in other types of stress. DiPaola and Beard (1992) reviewed physiological effects of temperature stress and reported a clear association between carbohydrate reserves vs. resistance to freezing and heat stress.

Greater understanding of the effects of TGRs on carbohydrate accumulation may aid in their use to help hasten acclimation to stress, mitigate stress symptoms, and aid in recovery after stress periods. The objective of this study on tall fescue was to determine the effect of a single TE application on tissue weight and TNC concentration and weight in leaves, crowns, and roots when sampled 6 to 7 weeks following treatment. This sampling time was chosen to coincide with the 28- to 56-d callback schedule that professional lawn care personnel follow when working with tall fescue.

\section{Materials and Methods}

Field studies were conducted in 1995 and 1996 on 'Bonsai' tall fescue grown on a native soil classified as a Hanford fine sandy loam (coarse-loamy, mixed, Thermic Haplic Durixeralf). The research plot was seeded at a rate of $391 \mathrm{~kg} \cdot \mathrm{ha}^{-1}$ on 28 Sept. 1993 at the turfgrass research facility at the Univ. of California, Riverside.

The experimental design was a randomized complete-block design with seven replications, and the plots were re-randomized for the second year. No treatment carryover effects from the 1995 study were observed nor expected during the 1996 study. Individual plots measured $1.5 \times 1.2 \mathrm{~m}$. Trinexapac-ethyl was applied according to label instructions at a rate of $290 \mathrm{~g} \cdot \mathrm{ha}^{-1}$ a.i. on 17 Aug. 1995 and 16 Aug. 1996 with a backpack $\mathrm{CO}_{2}$-pressurized sprayer calibrated to deliver 408 and $815 \mathrm{~L} \cdot \mathrm{ha}^{-1}$ in 1995 and 1996, respectively. Control plots received no growth regulator.

Tall fescue in the experiment was maintained at a high level in 1995 and at a moderate level in 1996. Though the high level of maintenance is used on some tall fescue sites, it was adjusted to a moderate level of maintenance in 1996 so that it would be more representative of commonly used practices. The high level of maintenance consisted of $\mathrm{N}$ applications every 2 weeks for a total rate of $49 \mathrm{~kg} \cdot \mathrm{ha}^{-1}$ per month with a granular fertilizer $(22 \mathrm{~N}-1.3 \mathrm{P}-$ $7.5 \mathrm{~K}$ with ammonium and nitrate as the $\mathrm{N}$ source), and two mowings per week at a 38$\mathrm{mm}$ cutting height. The moderate level of maintenance consisted of $\mathrm{N}$ applications every 2 weeks for a total rate of $24 \mathrm{~kg} \cdot \mathrm{ha}^{-1}$ per month with a granular fertilizer $(16 \mathrm{~N}-2.6 \mathrm{P}-$ $6.6 \mathrm{~K}$ with ammonium as the $\mathrm{N}$ source), and one mowing per week at a $38-\mathrm{mm}$ cutting height. During both years, mowing was conducted with a 53-cm-wide, walk-behind rotary mower with clippings collected. Irrigation scheduling was based upon reference 
evapotranspiration $\left(\mathrm{ET}_{\mathrm{o}}\right)$, utilizing data from an on-site weather station. Irrigation application was $\approx 100 \mathrm{ET}_{\text {o }}$ plus supplemental irrigation when necessary to prevent visual drought symptoms.

Plots were rated for visual turfgrass quality using a 1 to 9 scale, where $1=$ dead or completely brown turf, $5=$ minimally acceptable, and $9=$ maximum tall fescue quality. Plots were rated four times in 1995,9 to $52 \mathrm{~d}$ after treatment (DAT), and five times in 1996, 19 to 54 DAT.

Clipping yields from $0.52 \mathrm{~m}^{2}$ were collected weekly from each plot utilizing the same mower used for routine mowing. During this time, the mower was equipped with a yield-box attachment. Clipping yields were from 4-d growth in 1995 and 7-d growth in 1996. They were dried for $48 \mathrm{~h}$ in a forced-air oven maintained at $60{ }^{\circ} \mathrm{C}$ and weighed. Clipping yield data are reported as $\mathrm{g} \cdot \mathrm{m}^{-2}$ per $4 \mathrm{~d}$ for 1995 and $\mathrm{g} \cdot \mathrm{m}^{-2}$ per $7 \mathrm{~d}$ for 1996 . Cumulative clipping yield was calculated as the sum of clipping yields from all collection dates within a year. Percentage yield reduction was calculated for each collection date and cumulative clipping yield as the absolute value of: [(treated - nontreated control)/nontreated control] $\times$ 100 .

Cores were extracted on 28 Sept. 1995 (42 DAT) and 4 Oct. 1996 (49 DAT) to measure TNC in leaves, crowns, and roots. Four cores were extracted from each plot to a $15.0-\mathrm{cm}$ depth using a 10.2-cm-diameter cup cutter. The cores were cut at the soil-thatch line, pooled into soil and crown cores, sealed in Ziploc $^{\circledR}$ (Dow Brands L.P., Indianapolis) freezer bags, frozen, and stored at $-24{ }^{\circ} \mathrm{C}$ for later analysis. After thawing the soil cores, roots were washed free of soil, sealed inZiploc ${ }^{\circledR}$ freezer bags, frozen, and stored at $-24{ }^{\circ} \mathrm{C}$ for later heat killing and drying. After thawing the crown cores, soil was removed by washing, and any remaining roots were removed and added to the appropriate bag containing roots. Crown and leaf parts were separated by identifying the oldest green leaf collar and excising the leaf one-third the distance from the crown to the oldest leaf collar (Spak et al., 1993). Thus, crown parts included a small portion of leaf sheath that was normally not green. All tissue with the appearance of a leaf, regardless of color, was saved and added to the leaf parts. Remaining plant tissue that was too decomposed to be identified as leaf or crown parts was discarded. Crown and leaf parts were individually sealed in freezer bags, frozen, and stored at $-24{ }^{\circ} \mathrm{C}$ for later heat killing and drying.

All tissue was heat-killed for $1 \mathrm{~h}$ in a forced-air oven maintained at $100^{\circ} \mathrm{C}$ and then dried for 48 to $60 \mathrm{~h}$ in the same oven maintained at $70{ }^{\circ} \mathrm{C}$ (George et al., 1989). Dried tissue was weighed and is reported as $\mathrm{g} \cdot \mathrm{cm}^{-2}$ for leaf and crown tissue and as $\mathrm{g} \cdot \mathrm{cm}^{-3}$ for root tissue. Within 1 week after weighing, the tissue was ground in a Wiley-Mill to pass through a $0.425-\mathrm{mm}$ sieve, stored in coin envelopes, and mailed to the Univ. of California Division of Agricultural and Natural Resources analytical laboratory (Davis) for TNC analysis.

One procedure measured sucrose and glucose and the second procedure measured fructose resulting from hydrolysis of short-chain fructosans. First, a 250-mg tissue sample was mixed with water and heated at $90^{\circ} \mathrm{C}$ for $1 \mathrm{~min}$ to yield free sugars and to gelatinize starch present in the tissue. The gelatinized starch was hydrolyzed with amyloglucosidase $(4 \%$ $\mathrm{w} / \mathrm{v}$ ) in a $0.2 \mathrm{M}$ sodium acetate buffer solution (pH 4.9), and incubated at $50{ }^{\circ} \mathrm{C}$ for $24 \mathrm{~h}$, to yield free glucose. Sucrose and glucose in the supernatant were quantified using high performance liquid chromatography (HPLC). The HPLC unit was equipped with an ion exchange column (Fast Carbohydrate Column, lead ionic form, Bio-Rad Laboratories, Hercules, Calif.) heated to $75{ }^{\circ} \mathrm{C}$ and a guard column (Carbo-P, Bio-Rad Laboratories). Water was used as eluent at a flow rate of 0.8 $\mathrm{mL} \cdot \mathrm{min}^{-1}$. Sucrose and glucose were quantified with a refractive index detector (RID-6A, Shimadzu Scientific Instruments, Inc., Columbia, Md.).

A modified acid hydrolysis procedure (Smith and Grotelueschen, 1966) yielded fructose molecules from short-chain fructosans (Smith, 1968). A second 250-mg tissue sample was hydrolyzed with $0.45 \mathrm{~N} \mathrm{H}_{2} \mathrm{SO}_{4}$ at $105^{\circ} \mathrm{C}$ for $15 \mathrm{~min}$. The solution was cooled and 0.45 $\mathrm{N} \mathrm{NaOH}$ was added to neutralize the acid. The supernatant was then filtered and fructose content was quantified using HPLC as described above. Because the hydrolysis procedure yielded fructose from sucrose, one-half of the sucrose concentration measured in the amyloglucosidase hydrolysis procedure was subtracted from the fructose concentration resulting from acid hydrolysis. The resultant adjusted fructose concentration was derived solely from fructosan molecules. Total nonstructural carbohydrate data represent the sum of glucose, sucrose, and adjusted fructose determinations. Data are expressed both as TNC concentration $\left(\mathrm{mg} \cdot \mathrm{g}^{-1} \mathrm{DW}\right)$ and as TNC weight per unit upper surface area of the crown cores for leaves and crowns and as per unit volume of the soil cores for roots.

Analysis of variance (ANOVA) was performed at each maintenance level for clipping yield and turfgrass quality on each measurement date, and on cumulative clipping yield. Also, a repeated measures ANOVA was performed for turfgrass quality to test TE treatment, date, and TE treatment $\times$ date effects at each maintenance level. The TNC data were analyzed at each maintenance level for each plant part with a randomized complete-block design, and also as a split-plot design, with TE treatment as the main plot factor and plant part as the subplot factor. A combined ANOVA tested main effects of maintenance level, TE treatment, and plant part plus all interaction effects for TNC data, and Fisher's protected least significant difference (LSD) test was used for mean separations.

\section{Results and Discussion}

Trinexapac-ethyl effects on clipping yield and turfgrass quality. Clipping yields were significantly reduced by TE treatment from 6 to 34 DAT under the high turfgrass maintenance level (1995) and from 11 to 39 DAT under the moderate turfgrass maintenance level (1996) (Table 1). Reductions in clipping yield ranged from $44 \%$ to $77 \%$ at various dates during 1995 and from $17 \%$ to $50 \%$ during 1996 , totaling $61 \%$ in 1995 but only $30 \%$ in 1996.

Factors influencing turfgrass growth and vigor, such as environment and level of turfgrass maintenance, can influence the response of turfgrasses to TGRs. However, we believe the greater growth suppression during 1995 was related to greater TE activity. Two observations (daily growth rates and turfgrass quality ratings) support this hypothesis. Average daily growth rates were calculated for 1995 as: (cumulative yield)/20 d and for 1996 as: (cumulative yield)/35 d. The average daily growth rate of the nontreated control was 2.3 $\mathrm{g} \cdot \mathrm{m}^{-2}$ during 1995 and $1.8 \mathrm{~g} \cdot \mathrm{m}^{-2}$ during 1996 vs. 0.9 and $1.2 \mathrm{~g} \cdot \mathrm{m}^{-2}$ in 1995 and 1996 , respectively, for the TE-treated plots. Thus, the average daily growth rate of the nontreated control was higher in 1995 than in 1996 and was consistent with the higher level of turfgrass

Table 1. The effect of trinexapac-ethyl (TE) (one application of $290 \mathrm{~g} \cdot \mathrm{ha}^{-1}$ a.i.) on clipping yield of tall fescue during 1995 and 1996.

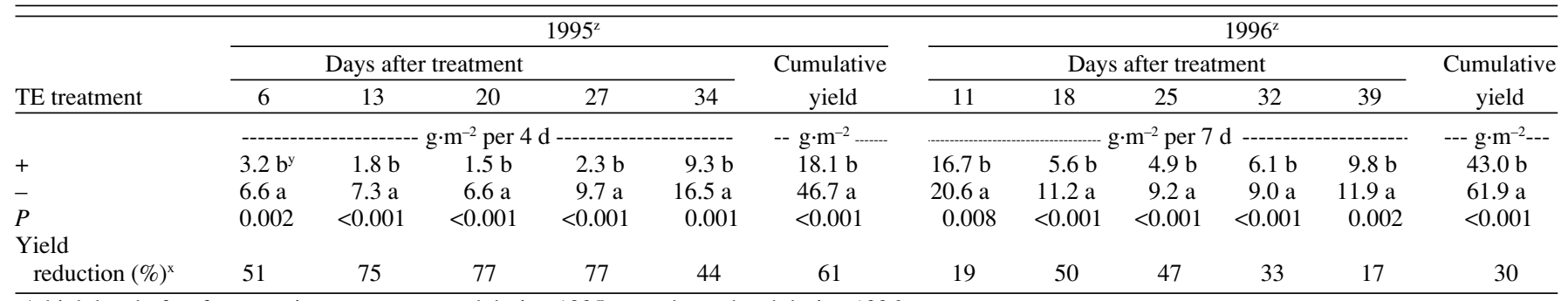

${ }^{\mathrm{z}} \mathrm{A}$ high level of turfgrass maintenance was used during 1995, a moderate level during 1996.

y Mean separation within columns by Fisher's protected LSD, $P \leq 0.05$.

Xercentage of yield reduction calculated as the absolute value of: [(treated - nontreated control)/nontreated control] $\times 100$. 
Table 2. The effect of trinexapac-ethyl (TE)(one application of $290 \mathrm{~g} \cdot \mathrm{ha}^{-1}$ a.i.) on visual turfgrass quality ratings $\mathrm{s}^{\mathrm{z}}$ of tall fescue during 1995 and 1996.

\begin{tabular}{|c|c|c|c|c|c|c|c|c|c|c|c|}
\hline \multirow[b]{3}{*}{ TE treatment } & \multicolumn{5}{|c|}{$1995^{\mathrm{y}}$} & \multicolumn{6}{|c|}{$1996^{y}$} \\
\hline & \multicolumn{4}{|c|}{ Days after treatment } & \multirow[b]{2}{*}{ Overall } & \multicolumn{5}{|c|}{ Days after treatment } & \multirow[b]{2}{*}{ Overal } \\
\hline & 9 & 16 & 31 & 52 & & 19 & 26 & 33 & 40 & 54 & \\
\hline$\overline{+}$ & $6.8 \mathrm{a}^{\mathrm{x}}$ & $5.5 \mathrm{~b}$ & $5.9 \mathrm{~b}$ & $7.4 \mathrm{a}$ & $6.4 \mathrm{~b}$ & $6.5 \mathrm{a}$ & $6.4 \mathrm{a}$ & $6.4 \mathrm{a}$ & $6.4 \mathrm{a}$ & $6.4 \mathrm{a}$ & $6.4 \mathrm{a}$ \\
\hline \multicolumn{12}{|l|}{$P^{\mathrm{w}}$} \\
\hline TE treatment $(\mathrm{T})$ & 1.000 & 0.001 & $<0.001$ & 0.374 & $<0.001$ & 0.788 & 0.457 & 0.604 & 0.200 & 0.407 & 0.429 \\
\hline Date (D) & & & & & $<0.001$ & & & & & & 0.031 \\
\hline
\end{tabular}

${ }^{2}$ Visual turfgrass quality ratings were on a 1 to 9 scale, where $1=$ dead or completely brown turf; $5=$ minimally acceptable; and $9=$ maximum tall fescue quality. ${ }^{y}$ A high level of turfgrass maintenance was used during 1995, a moderate level during 1996.

${ }^{\times}$Mean separation within columns by Fisher's protected LSD, $P \leq 0.05$.

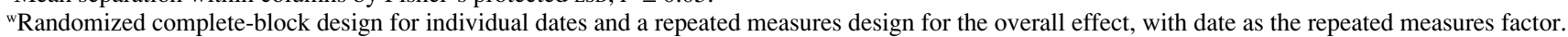

maintenance used during 1995. In contrast, the average daily growth rate of the TE-treated tall fescue was higher in 1996 than in 1995. This would not have been true had TE activity been similar during both years. The second supporting observation is that turfgrass quality ratings were significantly reduced by TE treatment on two rating dates and overall in 1995, but there was no reduction in 1996 (Table 2 ). The reduction in 1995 was due to phytotoxicity, probably associated with a greater amount of TE activity. Note that turfgrass quality ratings were acceptable in both years.

Trinexapac-ethyl, plant part, and maintenance level effects on tissue weight and TNC concentration and weight. A single application of trinexapac-ethyl at $290 \mathrm{~g} \cdot \mathrm{ha}^{-1}$ a.i. under a high (1995) or moderate (1996) turfgrass maintenance level did not increase tissue weight or TNC concentration and weight in leaves, crowns, or roots when sampled 42 DAT in 1995 and 49 DAT in 1996 (Table 3). Crowns contained the highest TNC concentration, whereas leaves had the highest tissue and TNC weight (data not shown).

Results of a combined ANOVA over both turfgrass maintenance levels showed that the maintenance level $\times$ TE treatment interaction was nonsignificant for tissue weight or TNC concentration and weight (data not shown). Thus, the effects of TE treatment on these variables were consistent regardless of turfgrass maintenance level. Other results from the combined ANOVA showed that turfgrass maintenance level significantly affected TNC concentration and tissue weight, but not TNC weight. The TNC concentration was significantly higher in crowns and roots during 1996 and tissue weight was significantly higher in leaves and roots during 1995.

In summary, one application of TE at the label rate of $290 \mathrm{~g} \cdot \mathrm{ha}^{-1}$ a.i. should have increased TNC weight because of growth suppression, and have inhibited leaf growth by $50 \%$ over a 4 -week period. Clipping yields taken 6 to 27 DAT under the high turfgrass maintenance level (1995) and 11 to 25 DAT under the moderate turfgrass maintenance level (1996), indicated yield reductions of $71 \%$ during 1995 and 34\% during 1996 (data not shown). Thus, the amount of growth inhibition exceeded product label expectations in 1995 and was below expectations in 1996. Ideally, to test the hypothesis, the amount of growth inhibition should have been adequate during both years. Although TE provided reasonable growth inhibition for a 4-week period, it did not increase tissue weight or TNC concentration and weight in leaves, crowns, and roots when sampled 42 DAT in 1995 and 49 DAT in 1996. Our data are indirectly supported by other reports involving TGR-treated cool-season turfgrass species (Cooper et al., 1988; Han et al., 1998; Spak et al., 1993). These reports indicated that the increase of carbohydrates in certain plant parts was short-lived, relatively soon after TGR application (2 to 4 weeks). Following this initial period, TGR application(s) reduced or had no effect on carbohydrate levels in certain plant parts.

Professional lawn care personnel who are maintaining tall fescue on a 28 - to 56-d callback schedule and desire to precondition tall fescue to stress conditions by the accumulation of TNC in plant parts may need to consider a TE application every $28 \mathrm{~d}$ or more often. Research is needed to test this schedule at various rates of TE and to take samples for TNC analysis at various times during the study. If the callback schedule is $>35$ to $42 \mathrm{~d}$, rates of TE higher than $290 \mathrm{~g} \cdot \mathrm{ha}^{-1}$ may need to be used at each visit. Research is also needed to test if TE-induced accumulations of TNC actually result in stress reduction, especially under field conditions.

Table 3. The effect of trinexapac-ethyl (TE) (one application of $290 \mathrm{~g} \cdot \mathrm{ha}^{-1}$ a.i.) and plant part on tissue weight and on TNC concentration and weight of tall fescue during 1995 and 1996.

\begin{tabular}{|c|c|c|c|c|c|c|}
\hline \multirow[b]{2}{*}{ TE treatment } & \multicolumn{3}{|c|}{$1995^{z}$} & \multicolumn{3}{|c|}{$1996^{z}$} \\
\hline & Tissue wt & TNC concn & TNC wt & Tissue wt & TNC concn & TNC wt \\
\hline & \multicolumn{6}{|c|}{ Leaves } \\
\hline & $--\mathrm{mg} \cdot \mathrm{cm}^{-2}$ & $\mathrm{mg} \cdot \mathrm{g}^{-1}$ & $\mu \mathrm{g} \cdot \mathrm{cm}^{-2}$ & $\mathrm{mg} \cdot \mathrm{cm}^{-2}$ & $\mathrm{mg} \cdot \mathrm{g}^{-1}$ & $\mu \mathrm{g} \cdot \mathrm{cm}^{-2}$ \\
\hline+ & $48.5 \mathrm{a}^{\mathrm{y}}$ & $37.1 \mathrm{a}$ & $1,795 \mathrm{a}$ & $41.5 \mathrm{a}$ & $41.8 \mathrm{a}$ & $1728 \mathrm{a}$ \\
\hline \multirow[t]{3}{*}{-} & $46.0 \mathrm{a}$ & $42.8 \mathrm{a}$ & $1,962 \mathrm{a}$ & $39.6 \mathrm{a}$ & $44.5 \mathrm{a}$ & $1768 \mathrm{a}$ \\
\hline & \multicolumn{6}{|c|}{ Crowns } \\
\hline & $--\mathrm{mg} \cdot \mathrm{cm}^{-2}$ & $\mathrm{mg} \cdot \mathrm{g}^{-1}$ & $\mu \mathrm{g} \cdot \mathrm{cm}^{-2}$ & $\mathrm{mg} \cdot \mathrm{cm}^{-2}$ & $\mathrm{mg} \cdot \mathrm{g}^{-1}$ & $\mu \mathrm{g} \cdot \mathrm{cm}^{-2}$ \\
\hline+ & $3.7 \mathrm{a}$ & $54.7 \mathrm{a}$ & $204 \mathrm{a}$ & $3.0 \mathrm{a}$ & $93.2 \mathrm{~b}$ & $285 \mathrm{a}$ \\
\hline \multirow[t]{3}{*}{-} & $3.4 \mathrm{a}$ & $63.3 \mathrm{a}$ & $215 \mathrm{a}$ & $2.9 \mathrm{a}$ & $100.0 \mathrm{a}$ & $290 \mathrm{a}$ \\
\hline & \multicolumn{6}{|c|}{ Roots } \\
\hline & $--\mathrm{mg} \cdot \mathrm{cm}^{-3}$ & $\mathrm{mg} \cdot \mathrm{g}^{-1}$ & $\mu \mathrm{g} \cdot \mathrm{cm}^{-3}$ & $\mathrm{mg} \cdot \mathrm{cm}^{-3}$ & $\mathrm{mg} \cdot \mathrm{g}^{-1}$ & $\mu \mathrm{g} \cdot \mathrm{cm}^{-3}$ \\
\hline+ & $0.5 \mathrm{a}$ & $29.3 \mathrm{a}$ & $13 \mathrm{a}$ & $0.4 \mathrm{a}$ & $41.9 \mathrm{a}$ & $15 \mathrm{~b}$ \\
\hline- & $0.5 \mathrm{a}$ & $32.4 \mathrm{a}$ & $18 \mathrm{a}$ & $0.4 \mathrm{a}$ & $45.8 \mathrm{a}$ & $17 \mathrm{a}$ \\
\hline \multicolumn{7}{|l|}{$P^{\mathrm{x}}$} \\
\hline TE treatment $(\mathrm{T})$ & 0.122 & 0.116 & 0.288 & 0.199 & 0.041 & 0.854 \\
\hline Plant part $(\mathrm{P})$ & $<0.001$ & $<0.001$ & $<0.001$ & $<0.001$ & $<0.001$ & $<0.001$ \\
\hline $\mathrm{T} \times \mathrm{P}$ & 0.079 & 0.662 & 0.182 & 0.088 & 0.758 & 0.963 \\
\hline
\end{tabular}

${ }^{\mathrm{z}} \mathrm{A}$ high level of turfgrass maintenance was used during 1995, a moderate level during 1996.

'Mean separation within columns and plant parts by Fisher's protected LSD, $P \leq 0.05$. ANOVA was based on a randomized complete-block design.

${ }^{x}$ ANOVA based on a split-plot design; TE treatment $=$ main plot; plant part $=$ subplot. 
McCarty, E.C. 1935. Seasonal march of carbohydrates in Elymus ambiguus and Muhlenbergia gracilis and their reaction under moderate grazing use. Plant Physiol. 10:727-738.

Morgan, J.M. 1984. Osmoregulation and water stress in higher plants. Annu. Rev. Plant Physiol. 35:299-319.

Nelson, C.J., T.L. Vassey, and J.W. MacAdam. 1986. Morphology and physiology of meristems of graminaceous crops, p. 20-34. In: A. Cooke (ed.). Proc. Plant Growth Regulator Soc. Amer., 13th Annu. Mtg., St. Petersburg Beach, Fla. 3 7 Aug. 1986.

Perdomo, P., J.A. Murphy, and G.A. Berkowitz.
1996. Physiological changes associated with performance of Kentucky bluegrass cultivars during summer stress. HortScience 31:11821186.

Qian, Y.L. and M.C. Engelke. 1999. Influence of trinexapac-ethyl on Diamond zoysiagrass in a shade environment. Crop Sci. 39:202-208.

Smith, D. 1968. Classification of several native North American grasses as starch or fructosan accumulators in relation to taxonomy. J. Brit. Grassland Soc. 23:306-309.

Smith, D. and R.D. Grotelueschen. 1966. Carbohydrates in grasses: I. Sugar and fructosan composition of the stem bases of several northern- adapted grasses at seed maturity. Crop Sci. 6:263266

Spak, D.R., J.M. DiPaola, W.M. Lewis, and C.E. Anderson. 1993. Tall fescue sward dynamics: II. Influence of four plant growth regulators. Crop Sci. 33:304-310.

Watschke, T.L. 1976. Growth regulation of Kentucky bluegrass with several growth retardants. Agron. J. 68: 787-791.

White, L. 1973. Carbohydrate reserves of grasses: A review. J. Range Mgt. 26:13-18.

White, R.H., M.C. Engelke, S.J. Morton, and B.A. Ruemmele. 1992. Competitive turgor maintenance in tall fescue. Crop Sci. 32:251-256. 